\title{
ANALYSIS OF THE RISK FACTORS FOR INCIDENTAL CARCINOMA OF THE PROSTATE IN PATIENTS WITH BENIGN PROSTATIC HYPERPLASIA
}

\author{
Alberto Azoubel Antunes, Geraldo de Campos Freire, Domingos Aiello Filho, \\ José Cury, Miguel Srougi
}

\begin{abstract}
Antunes AA, Freire G de C, Aiello Filho D, Cury J, Srougi M. Analysis of the risk factors for incidental carcinoma of the prostate in patients with benign prostatic hyperplasia. Clinics. 2006;61(6):545-50.
\end{abstract}

PURPOSE: To determine the occurence of incidental carcinoma of the prostate, its characteristics, and the risk factors for this diagnosis in a group of patients surgically treated for benign prostatic hyperplasia.

METHODS: The study comprised a retrospective analysis of 218 patients. After surgical treatment, patients with the finding of incidental carcinoma of the prostate were compared to those without this finding. The preoperative variables analyzed were patient age, digital rectal examination, PSA, PSA density, prostate volume, and preoperative prostate biopsy. We also determined the sensitivity, specificity, positive predictive value, and negative predictive value of digital rectal examination and PSA for the finding of incidental carcinoma of the prostate at surgical specimen analysis.

RESULTS: Thirteen (6.2\%) out of the 218 patients presented incidental carcinoma of the prostate. Eight (61.5\%) of these tumors were classified as T1a and $5(38.5 \%)$ as T1b. Only advanced age $(\mathrm{P}=0.003)$ and the presence of a suspect digital rectal examination $(\mathrm{P}=0.016)$ were statistically related to the findings of the surgical specimen analysis. The sensitivity, specificity, positive predictive value, and negative predictive value for the diagnosis of incidental carcinoma were $23.0 \%, 96.6 \%, 30.0 \%$, and $95.2 \%$ for a suspect digital rectal examination and $85.0 \%, 34.1 \%, 7.5 \%$, and $97.2 \%$ for a PSA greater than $4.0 \mathrm{ng} / \mathrm{mL}$. The accuracy for these methods was $92.2 \%$ and $37.1 \%$, respectively.

CONCLUSIONS: Advanced age and the presence of a suspect digital rectal examination represent the most important risk factors for the diagnosis of an incidental carcinoma of the prostate. However, the low positive predictive values reflect the weak correlations among these variables.

KEYWORDS: Benign prostatic hyperplasia. Prostatectomy. Prostate-specific antigen. Prostatic neoplasms.

\section{INTRODUCTION}

Prostate cancer is the most common malignant tumor in men. ${ }^{1}$ Similarly, benign prostatic hyperplasia (BPH) is the most frequent benign tumor, and about $90 \%$ of the men are affected by the ninth decade of life. ${ }^{2}$ Since many of these individuals are going to be surgically treated by transurethral resection of the prostate (TURP) or open pros-

Division of Urology, São Paulo University Medical School - São Paulo/SP, Brazil.

Email: antunesuro@uol.com.br

Received for publication on July 03, 2006.

Accepted for publication on August 16, 2006. tatectomy (OP) to relieve bladder outlet obstruction, ${ }^{3,4}$ a significant rate of carcinoma is expected to be found incidental to surgical specimen analysis.

Incidental carcinoma of the prostate (ICP) refers to well differentiated tumors that grow in a transitional zone and are eventually found during TURP and OP. ${ }^{5}$ With the widespread use of prostate specific antigen (PSA) as a tumor marker for screening of prostate cancer, the incidence of ICP ranges between $4.3 \%$ and $7.4 \%$ of the surgical procedures for $\mathrm{BPH} .^{6-8}$

In spite of being considered tumors of low malignant potential, if not treated, the biological behavior of ICP may vary, and significant progression and death can occur. A 
study from the Mayo clinic reported progression rates of $8 \%$ to $37 \%$ for the T1a cases in a 10 year follow-up period. ${ }^{5}$ For this reason, the identification of parameters that could help in the preoperative diagnosis of these tumors is pivotal, since most patients would benefit from immediate curative treatment.

The aim of this study was to determine the incidence of ICP, its clinical and pathological characteristics, and the risk factors for this diagnosis in a group of patients with $\mathrm{BPH}$ treated surgically.

\section{MATERIALS AND METHODS}

The study comprised a retrospective analysis of 218 patients with clinical or pathologic findings of $\mathrm{BPH}$ who were treated with OP or TURP. In the preoperative period, patients were evaluated through digital rectal examination, serum PSA, acid phosphatases and creatinine, urine assays, and ultrasound to determine prostate volume.

A suspect digital rectal examination was defined as the presence of nodules or irregularities on the prostate surface. Every patient with a suspect digital rectal examination and/ or an increased baseline PSA suggestive of prostate cancer underwent preoperative transrectal ultrasound-guided prostate biopsy. Patients with the finding of prostate cancer were not considered for study. Ultrasound-based prostate volume was determined as previously described. ${ }^{9}$

All patients were treated surgically through TURP (169 patients) or OP (49 patients). Indications for surgery included the presence of severe low urinary tract symptoms that was unresponsive to clinical treatment, urinary retention, recurrent urinary tract infections, persistent hematuria, presence of bladder calculi or diverticula, or hydronephrosis due to BPH.

The retrieved prostate tissue was weighed, and surgical specimens were fixed in $10 \%$ formalin and forwarded to pathology for examination. This analysis included a semiquantitative determination of the percent of prostate tissue involved in the tumor. Pathological stage was defined by the 1992 American Joint Committee on Cancer (AJCC) staging system, ${ }^{10}$ and the Gleason score was used for analysis of histological grade. ${ }^{11}$

After surgical treatment, patients with the finding of ICP were compared to those with diagnosis of BPH. The preoperative variables analyzed were patient age, digital rectal examination, serum PSA, PSA density, prostate volume, and preoperative prostate biopsy.

For statistical analysis, we used Student $t$, Wilcoxon, chi-squared, and Fisher exact tests. Statistical significance was set as a $P$ value $\mathrm{d} \bullet 0.05$. We also determined the sensitivity, specificity, positive predictive value (PPV), and nega- tive predictive value (NPV) of digital rectal examination and serum PSA for the finding of ICP on surgical specimen analysis.

\section{RESULTS}

Table 1 shows the patient characteristics. The mean age was 67.9 years (49 to 90). The great majority of patients presented a nonsuspect digital rectal examination $(95.4 \%)$ and a PSA value between 4.0 and $10.0 \mathrm{ng} / \mathrm{mL}$ (41.7\%). The mean prostate volume was $65.4 \mathrm{~g}$, and about $27 \%$ of the patients had an indwelling bladder catheter due to acute urinary retention. Forty-seven percent of the patients underwent a transrectal ultrasound-guided prostate biopsy, and $77.5 \%$ of the patients were treated through TURP.

Thirteen $(6.2 \%)$ out of the 218 patients presented ICP. Eight $(61.5 \%)$ of these tumors were classified as T1a and $5(38.5 \%)$ as T1b. Table 2 shows the characteristics of the patients with ICP. Three patients with stage T1a tumors presented a suspect digital rectal examination, while no patients with stage T1b tumors presented this finding. The mean PSA for this last group was about half the value of the patients with stage T1a tumors. This finding can be explained by the fact that patients with stage T1a tumors had greater prostate volumes when compared to those with stage T1b tumors (83.1 g versus $54.2 \mathrm{~g}$ ). The majority of patients with T1b tumors were using an indwelling bladder catheter, and none underwent a preoperative prostate biopsy. The mean percent of prostate tissue retrieved from patients with stage T1a tumors was $49.2 \%$ versus $27.2 \%$ for patients with T1b tumors, which reflects the fact that 3 patients from the first group were treated through OP, in which a greater amount of adenoma is removed when compared to endoscopic techniques. All the patients with T1a tumors were treated with watchful-waiting, and among the 5 patients with T1b tumors, 2 were observed, 2 underwent radical prostatectomy, and 1 underwent bilateral orchidectomy because he was 82 years old and had a Gleason score of 9 (5 $+4)$.

Among the analyzed risk factors, only an advanced age $(P=0.003)$ and the presence of a suspect digital rectal examination $(P=0.016)$ were significantly related to the finding of ICP on surgical specimen analysis (Table 3 ). The mean age among patients with ICP was $73.9 \pm 11.2$ years, versus $68.0 \pm 7.4$ years among patients with BPH. Similarly, while $23 \%$ of the patients with ICP presented a suspect digital rectal examination, this finding was present in only $3.4 \%$ of the patients with BPH.

When we correlated the presence of a PSA value greater than $4.0 \mathrm{mg} / \mathrm{mL}$ with the finding of ICP among patients without an indwelling bladder catheter using the chi-squared test, 
Table 1 - Preoperative characteristics of the patients

\begin{tabular}{ll}
\hline Variables & \\
\hline Mean age (years) \pm SD & $67.9 \pm 7.8(49$ to 90$)$ \\
Median & 68 \\
Digital rectal examination & $208(95.4 \%)$ \\
Nonsuspect & $10(4.6 \%)$ \\
Suspect & \\
PSA (ng/mL) & $72(33.0 \%)$ \\
$<4.0$ & $91(41.7 \%)$ \\
4.0 to 10.0 & $55(25.2 \%)$ \\
$>10.0$ & $162(74.3 \%)$ \\
PSA density & $56(25.7 \%)$ \\
$<0.15$ & $65.4 \pm 33.6$ \\
$>0.15$ & $(21$ to 166.3$)$ \\
Mean prostate volume $(\mathrm{g}) \pm \mathrm{SD}$ & 57.1 \\
(min-max) & \\
Median & $59(27.1 \%)$ \\
Presence of bladder catheter & $159(72.9 \%)$ \\
Yes & $102(46.8 \%)$ \\
No & $116(53.2 \%)$ \\
Transrectal prostate biopsy & \\
Yes & $169(77.5 \%)$ \\
No & $49(22.5 \%)$ \\
Surgery &
\end{tabular}

SD: Standard deviation.

Table 2 - Characteristics of the patients with Characteristics of patients with stage T1b incidental prostate cancer (ICP)

\begin{tabular}{lll}
\hline & Stage & \\
& T1A $(8$ cases $)$ & T1B(5 cases $)$ \\
\hline Mean age (years) & 74.8 & 72.4 \\
Suspected rectal examination & $3(37.5 \%)$ & $0(0.0 \%)$ \\
Mean prostate weight $(\mathrm{g})$ & 83.1 & 54.2 \\
Mean PSA (ng/mL) & 12.7 & 6.6 \\
Mean PSA density $(\mathrm{ng} / \mathrm{mL} / \mathrm{g})$ & 0.17 & 0.12 \\
Presence of bladder catheter & $3(37.5 \%)$ & $3(60.0 \%)$ \\
Preoperative prostate biopsy & $6(75.0 \%)$ & $0(0.0 \%)$ \\
Surgery & & $5(100.0 \%)$ \\
TURP & $5(62.5 \%)$ & $0(0.0 \%)$ \\
OP & $3(37.5 \%)$ & 27.2 \\
Percent tissue removed $(\%)$ & 49.2 & $2(40.0 \%)$ \\
Definitive treatment & & $2(40.0 \%)$ \\
Watchful-waiting & $8(100 \%)$ & $1(20.0 \%)$ \\
Radical prostatectomy & $0(0.0 \%)$ & \\
Orchidectomy & $0(0.0 \%)$ & \\
\hline
\end{tabular}

this variable was not statistically significant $(P=0.220)$. The presence of a preoperative negative prostate biopsy for carcinoma did not exclude the possibility of ICP on surgical specimen analysis, because $6(5.8 \%)$ out of 102 patients with a negative prostate biopsy had this finding.

The sensitivity, specificity, PPV, and NPV for the diagnosis of ICP were $23.0 \%, 96.6 \%, 30.0 \%$, and $95.2 \%$ for a suspect digital rectal examination and $85.0 \%, 34.1 \%$, $7.5 \%$, and $97.2 \%$ for a serum PSA greater than $4.0 \mathrm{ng} / \mathrm{mL}$ respectively. The accuracy for these methods was $92.2 \%$ and $37.1 \%$, respectively.

\section{DISCUSSION}

Preoperative identification of cases with ICP is pivotal for institution of early radical curative treatment. In the present study, $6.2 \%$ of the patients presented ICP. Of these, $61.5 \%$ and $38.5 \%$ of the tumors were classified as T1a or T1b, respectively. Among the analyzed risk factors, only the presence of an advanced age and a suspect digital rectal examination showed a significant relationship with the finding of ICP. The mean age of patients with ICP was about 6 years greater than patients with $\mathrm{BPH}$, and the find- 
Table 3 - Risk factors for diagnosis of Characteristics of patients with stage T1b incidental prostate cancer (ICP)

\begin{tabular}{llll}
\hline Variable & ICP(13 patients) & BPH(205 patients) & $P$ value \\
\hline $\begin{array}{l}\text { Mean age (years) } \pm \text { SD } \\
\text { Rectal examination }\end{array}$ & $73.9 \pm 11.2$ & $68.0 \pm 7.4$ & $0.003 *$ \\
Suspect & $3(23.0 \%)$ & $7(3.4 \%)$ & $0.016^{* *}$ \\
Nonsuspect & $10(76.9 \%)$ & $198(96.5 \%)$ & $0.159 * *$ \\
PSA $(\mathrm{ng} / \mathrm{mL})$ & $2(15.3 \%)$ & $70(34.1 \%)$ & \\
$<4.0$ & $5(38.4 \%)$ & $86(41.9 \%)$ & $0.326 * *$ \\
4.0 to 10.0 & $6(46.1 \%)$ & $49(23.9 \%)$ & \\
$>10.0$ & $8(61.5 \%)$ & $154(75.1 \%)$ & $0.179 * * *$ \\
PSA density & $5(38.4 \%)$ & $51(24.8 \%)$ & \\
$<0.15$ & $72 \pm 28.8$ & $65 \pm 33.9$ & \\
$\geq 0.15$ & $6(46.1 \%)$ & $96(46.8 \%)$ & $109(53.1 \%)$ \\
Mean prostate volume $(\mathrm{g}) \pm \mathrm{SD}$ & $7(53.8 \%)$ & & \\
Preoperative prostate biopsy & Yes & & \\
No & &
\end{tabular}

* Student $t$ test; ** Fisher exact test; *** Wilcoxon test; BPH = benign prostate hypertrophy; PSA = prostate-specific antigen

ing of a suspect digital examination was 7 times more frequent among patients with ICP when compared to patients with BPH.

The finding of an ICP has been less frequent during the last decades. An analysis from the Utah cancer registry in the United States showed that the detection rates of ICP through TURP in men with 45 years or more were $39.0 \%$ between 1980 and 1984, 33.9\% between 1985 and 1989, 12.2\% between 1990 and 1994, and 7.4\% between 1995 and $1999 .{ }^{6}$ A possible explanation for these numbers is the decrease in the TURP rates since 1987. ${ }^{12}$ A North American study showed that when comparing the periods of 1984 to 1990 with 1991 to 1997 , the TURP rates decreased from 14.6 to 6.7 for 1000 white men and from 11.8 to 6.5 for 1000 black men respectively. ${ }^{13}$

In part, this finding can be explained by the increased number of patients treated with alpha-blockers or other alternative methods for treating BPH and even by the increasing role of the patients in the final therapeutic decision. ${ }^{6,12}$ Furthermore, with the widespread use of PSA and the increased acceptance and development of transrectal ultrasound guided prostate biopsy techniques, many patients were found to have prostate cancer and underwent specific treatment. ${ }^{6}$

Most frequently, patients with the diagnosis of ICP present well differentiated tumors with low malignant potential. A study comparing the cases of prostate cancer found through prostate biopsy with the ICP cases diagnosed by TURP showed organ-confined rates of $81.6 \%$ versus $95.9 \%$, respectively. Similarly, the well or moderately differentiated tumor rates were greater among the ICP cases when compared to tumors found through prostate biopsy (89.7\% against $80.7 \%$ respectively). ${ }^{6}$ However, a study of 786 patients with BPH treated by TURP found a $4.3 \%$ ICP rate and demonstrated that $32.3 \%$ of these presented a Gleason score of 7 to $10 .^{8}$

The mean age and mean PSA value among patients with stage T1a tumors was 70.1 years and $3.3 \mathrm{ng} / \mathrm{mL}$, and among patients with stage T1b tumors was 74 years and $2.9 \mathrm{ng} /$ $\mathrm{mL}$, respectively. When compared with the rest of the group, patients with ICP were older and had prostates with smaller volumes. ${ }^{8}$ In the present study, $1(7.6 \%)$ out of the 13 cases with ICP presented a Gleason score of $9(5+4)$. This patient was 82 years old, had a nonsuspect digital examination, a $65 \mathrm{~g}$ prostate, and a PSA value of $6.6 \mathrm{ng} / \mathrm{mL}$; for these reasons, he did not undergo a preoperative prostate biopsy. This finding confirms the necessity of finding these cases preoperatively, since there may be a significant number of these tumors with aggressive biological behavior. Only $3(23.0 \%)$ out of the 13 patients underwent definitive treatment.

Surprisingly, the presence of a high PSA value was not related with the finding of ICP. Despite its widespread use as a tumor marker, PSA is prostate tissue-specific and not prostate cancer-specific; therefore, the serum levels may also be altered in cases of BPH and prostatitis. ${ }^{14}$ One possible explanation for the lack of relationship between high PSA values and the finding of ICP among patients with urinary retention is the presence of the indwelling bladder catheter. However, when we analyzed the presence of high PSA levels among the 159 patients without bladder catheters this variable remained without significance. Possibly, the limited number of patients with the finding of ICP is the reason why we did not find a significant relationship.

In the present study, the finding of a negative prostate biopsy did not exclude the possibility of ICP upon surgical specimen analysis, since $5.8 \%$ of the patients with a negative biopsy presented this finding. We know that when a pros- 
tate biopsy is performed with the standard sextant technique, the false negative rate is about $20 \%$ to $25 \% .{ }^{15}$ Furthermore, due to its low specificity, when a prostate biopsy is performed in patients with PSA values $>3 \mathrm{ng} / \mathrm{mL}, 70 \%$ to $80 \%$ of the cases will present negative results for cancer. ${ }^{16}$

Finally, with the present study, we conclude that an advanced age and the presence of a suspect digital rectal examination for prostate cancer represent the most important risk factors for the diagnosis of an ICP. However, the low
PPV reflects the weak correlation between these variables and the finding of an ICP. These results mean that new methods for the preoperative diagnosis of the patients with ICP are needed. Perhaps with the development of molecular techniques that allow the differentiation between benign and malignant prostate tissue through determination of the cellular gene expression profile, ${ }^{17}$ these tumors could be easily detected, favoring the institution of early curative specific treatment.

\section{RESUMO}

Antunes AA, Freire G de C, Aiello Filho D, Cury J, Srougi M. Análise dos fatores de risco para o diagnóstico do carcinoma incidental da próstata em pacientes com hiperplasia prostática benigna. Clinics. 2006;61(6):545-50.

OBJETIVO: Determinar a ocorrência do carcinoma incidental da próstata, suas características e fatores de risco para o diagnóstico em um grupo de pacientes tratados cirurgicamente para hiperplasia prostática benigna.

MÉTODOS: O estudo compreendeu a análise retrospectiva de 218 pacientes. Após o tratamento cirúrgico, os pacientes com achado de carcinoma incidental da próstata foram comparados com os pacientes sem este achado. As variáveis pré-operatórias analisadas foram idade, toque retal, PSA, densidade do PSA, volume prostático e biópsia prostática pré-operatória. Também foram determinados a sensibilidade, especificidade, valor preditivo positivo e valor preditivo negativo do toque retal e do PSA para o diagnóstico do carcinoma incidental da próstata.

RESULTADOS: Treze $(6.2 \%)$ dos 218 pacientes apre- sentaram carcinoma incidental da próstata. Oito $(61.5 \%)$ deles foram classificados com T1a e 5 (38.5\%) como T1b. Apenas a idade avançada $(\mathrm{p}=0.003)$ e a presença de um toque retal suspeito $(\mathrm{p}=0.016)$ se relacionaram estatisticamente com este achado na peça cirúrgica. A sensibilidade, especificidade, valore preditivo positivo e negativo para o diagnóstico de carcinoma incidental da próstata foram de $23.0 \%, 96.6 \%, 30.0 \%, 95.2 \%$ para a presença de um toque retal suspeito e $85.0 \%, 34.1 \%, 7.5 \%$ e $97.2 \%$ para um valor de PSA maior que $4.0 \mathrm{ng} / \mathrm{ml}$ respectivamente. A exatidãos dois métodos foi de $92.2 \%$ e $37.1 \%$ respectivamente.

CONCLUSÕES: A idade avançada e a presença de um toque retal suspeito representam os fatores de risco mais importantes para o diagnóstico de carcinoma incidental da próstata.

UNITERMOS: Hiperplasia prostática benigna. Prostatectomia. Antígeno prostático específico. Neoplasias prostáticas. 


\section{REFERENCES}

1. Jemal A, Murray T, Ward E, Samuels A, Tiwari RC, Ghafoor A, et al. Cancer statistics, 2005. CA Cancer J Clin. 2005;55:10-30.

2. Tchetgen MB, Oesterling JE. The role of prostate-specific antigen in the evaluation of benign prostatic hyperplasia. Urol Clin North Am. $1995 ; 22: 333-44$

3. Tubaro A, Carter S, Hind A, Vicentini C, Miano L. A prospective study of the safety and efficacy of suprapubic transvesical prostatectomy in patients with benign prostatic hyperplasia. J Urol. 2001;166:172-6.

4. Kuntz RM, Ahyai S, Lehrich K, Fayad A. Transurethral holmium laser enucleation of the prostate versus transurethral electrocautery resection of the prostate: a randomized prospective trial in 200 patients. J Urol. 2004;172:1012-6.

5. Bostwick DG. The pathology of incidental carcinoma. Cancer Surv. 1995;23:7-18.

6. Merrill RM, Wiggins CL. Incidental detection of population-based prostate cancer incidence rates through transurethral resection of the prostate. Urol Oncol. 2002;7:213-9.

7. Zigeuner RE, Lipsky K, Riedler I, Auprich M, Schips L, Salfellner M, et al. Did the rate of incidental prostate cancer change in the era of PSA testing? A retrospective study of 1127 patients. Urology. 2003;62:4515 .

8. Argyropoulos A, Doumas K, Farmakis A, Aristas O, Kontogeorgos G, Lykourinas M. Characteristics of patients with stage T1b incidental prostate cancer. Scand J Urol Nephrol. 2005;39:289-93.

9. Scheckowitz EM, Resnick MI. Imaging of the prostate. Benign prostatic hyperplasia. Urol Clin North Am. 1995;22:321-32.
10. Beahrs OH, Henson DE, Hutter RVP, Kennedy BJ, editors. American Joint Committee on Cancer Manual for Staging Cancer 1992; (4th edition) Philadelphia, PA, JB Lippincott.

11. Gleason DF. Histologic grading of prostate cancer: a perspective. Hum Pathol 1992;23:273-9.

12. Lu-Yao GL, Barry MJ, Chang CH, Wasson JH, Wennberg JE. Transurethral resection of the prostate among Medicare beneficiaries in the United States: time trends and outcomes. Prostate Patient Outcomes Research Team (PORT). Urology. 1994;44:692-8.

13. Wasson JH, Bubolz TA, Lu-Yao GL, Walker-Corkery E, Hammond CS, Barry MJ. Transurethral resection of the prostate among medicare beneficiaries: 1984 to 1997. For the Patient Outcomes Research Team for Prostatic Diseases. J Urol. 2000;164:1212-5.

14. Schalken JA, Bergh A, Bono A, Foster C, Gospadarowicz M, Isaacs WB, et al. Molecular prostate cancer pathology: current issues and achievements. Scand J Urol Nephrol Suppl. 2005;(216):82-93.

15. Mariappan $P$, Chong WL, Sundram M, Mohamed SR. Increasing prostate biopsy cores based on volume vs the sextant biopsy: a prospective randomized controlled clinical study on cancer detection rates and morbidity. BJU Int. 2004;94:307-10.

16. Djavan B, Zlotta A, Remzi M, Ghawidel K, Basharkhah A, Schulman $\mathrm{CC}$, et al. Optimal predictors of prostate cancer on repeat prostate biopsy: a prospective study of 1,051 men. J Urol. 2000;163:1144-8.

17. Russo G, Zegar C, Giordano A. Advantages and limitations of microarray technology in human cancer. Oncogene. 2003;22:6497-507. 